\title{
Life style risk factors for femoral neck fracture in Dr. Sardjito General Hospital, Yogyakarta
}

\author{
Helmiza Fahry, Sugeng Yuwana* \\ Division of Orthopedic and Traumatology, Department of Surgery, Dr. Sardjito General \\ Hospital/Faculty of Medicine, Universitas Gadjah Mada, Yogyakarta
}

DOI: http://dx.doi.org/10.19106/JMedSci005002201812

\section{ABSTRACT}

As life expentancy improved, the incidence of femoral neck fracture, as one of the most common traumatic injuries in the elderly, has also increased. Risk for fracture is not only determined by age and sex but also by the degree of osteoporosis and certain life-styles. The purpose of this study was to investigate life-style risk factors for femoral neck fracture in Dr. Sardjito General Hospital, Yogyakarta. In this case-control study, all patients with femoral neck fractures admitted to the Orthopedic Division and Traumatology, Department of Surgery in 2013-2014 was included as cases. Controls were subjects without fracture of similar age and sex. Data of corticosteroid use, habitual coffee consumption, visual acuity disorders, habitual use of slippers and engagement in routine sport activity were collected with questionnaires. We invited 63 patients (51 females and 12 males) and 63 controls. Corticosteroid use, habitual coffee consumption, visual acuity disorder and habitual use of slippers were risks factors for fractures, OR $(95 \% \mathrm{Cl})=7.5(2.9-21.6), \mathrm{p}$ $<0.001 ; 7.5$ (2.9-21.6), $p<0.001 ; 3.2$ (1.6-6.8), $p<0.001$ and 5.7 (2.7-12.6), $p<0.001$, respectively. Engagement in routine sport activity was a protecting factor, OR $(95 \% \mathrm{Cl})=$ $0.10(0.02-0.33), p<0.001$. In conclusion, corticosteroid use, habitual coffee consumption, visual acuity disorder and habitual use of slippers are risk for fractures, while engagement in routine sport is a protecting factor.

\section{ABSTRAK}

Seiring dengan meningkatnya usia harapan hidup, meningkat pula angka kejadian fraktur colum femur pada orang tua. Risiko terjadinya fraktur tidak hanya ditentukan oleh usia dan jenis kelamin tetapi juga derajat osteoporosis dan gaya hidup tertentu. Tujuan penelitian ini adalah untuk mengkaji hubungan antara berbagai faktor risiko gaya hidup terhadap kejadian fraktur colum femur di RSUP Dr. Sardjito Yogyakarta. Pada studi kasus-kontrol ini, semua penderita fraktur colum femur di Departemen Ortopedi tahun 2013-2014 dimasukkan sebagai kasus. Sebagai kontrol adalah subyek dengan jenis kelamin dan kelompok umur setara yang belum pernah mengalami fraktur. Data riwayat penggunaan steroid, kebiasaan minum kopi, gangguan visus, kebiasaan menggunakan sandal dan kebiasaan berolah raga dikumpulkan dengan pengisian kuesiener. Sebanyak 63 kasus (51 wanita and 12 laki-laki) serta 63 kontrol dilibatkan dalam penelitian. Riwayat penggunaan steroid, kebiasaan minum kopi, gangguan visus dan kebiasaan menggunakan sandal merupakan faktor risiko fraktur dengan rasio odds (IK 95\%) berturut-turut: 7.5 (2.9-21.6), $\mathrm{p}<0.001 ; 7.5$ (2.9-21.6), $\mathrm{p}<0.001 ; 3.2$ (1.6-6.8), $\mathrm{p}<0.001$ dan 5.7 (2.7-12.6), $\mathrm{p}<0.001$. Sebaliknya, kebiasaan berolah raga merupakan faktor protektif dengann rasio odds 
(IK 95\%): 0.10 (0.02-0.33), $\mathrm{p}<0.001$. Dapat disimpulkan, riwayat penggunaan steroid, kebiasaan minum kopi, gangguan visus dan kebiasaan menggunakan sandal merupakan faktor risiko fraktur, sedangkan kebiasaan berolah raga merupakan faktor protektif.

Key words: femoral neck fracture - corticosteroid - coffee - visual acuity - sport

\section{INTRODUCTION}

As life expectancy increased, the incidence of hip fractures, especially fracture of the femoral neck has also increased. In thirty years, this improvement of life expectancy will double the proportion of those ages more than 65 years. Without proper preventive measures, the increase in the proportion of elderly will naturally double the incidence of femoral neck fractures. ${ }^{1}$ Old age was a well known risk factor for osteoporosis and the decrease in muscle volume and strength. The incidence of femoral neck fractures was highest between the age of 70-80 years. It was also much more common in women, with ratio of 3 to 1 . The difference in the prevalence between gender, might be associated with longer life expectancy in women and higher prevalence of osteoporosis after menopause. Femoral neck fractures were also associated with any diseases that lead to the decreases in bone or muscle strength, such as osteomalacia, diabetes mellitus or stroke. ${ }^{2}$

Femoral neck fractures were less common in Africans compared to Asians or Caucasians. The reason for this lower incidence was not yet clear, however, it was known that Africans had higher bone mass and underwent slower bone loss after menopause. They also had sighly different bone structures. ${ }^{1}$ Beside age, gender and race associated risks for femoral neck fractures, there were also life styles' associated risk factors, such as the use of coticosteroid, habitual coffee consumption, etc. These risk factors were important to be looked into since they might be preventable. ${ }^{3}$

This study was conducted to investigate life-style risk factors for femoral neck fracture in patients presenting to Dr. Sardjito General Hospital Yogyakarta. In this study we focused on corticosteroid use, habitual coffee consumption, visual acuity disorders, habitual use of slippers or footwears and engagement in routine sport.

\section{MATERIALS AND METHODS}

\section{Subjects}

This was a case control study. The cases were all patients admitted to the Division of Orthopedic and Traumatology, Department of Surgery, Dr. Sardjito General Hospital due to femoral neck fracture between January 2012 to December 2014. Controls were subjects from the general population who had never had any femoral fracture, with similar age, gender and area of living. We excluded subjects with dementia or history of stroke or any other cerebrovascular problems.

\section{Protocol of study}

We used questionnaires to obtain data on age, sex and area of living as well as history of life-style risk factors. History of corticosteroid use was regarded as positive if subjects used any corticosteroid at least once per month. The corticosteroid use included those prescribed by medical doctor for any indication, i.e. allergy or asthma, etc., or those obtained illegaly over the counter.

History of coffee consumption was regarded as positive when subjects drank at least one glass or one cup of coffee daily. History of visual accuity disturbance was regarded as positive when subjects had to use eyeglasses or contact lenses, as well as medical diagnoses of cataract. Subjects were regarded as engaging in routine sport activities if he/she did it at least weekly. Furthermore, there was also question on the habitual use of slippers or other footwears at home. The study had obtained ethical 
approval from the Medical and Health Research Ethics Committee, Faculty of Medicine, Universitas Gadjah Mada/Dr. Sardjito General Hospital. Written informed concent were obtained from all participants.

\section{Statistical analysis}

Odd ratio or OR $(95 \% \mathrm{CI})$ were calculated from every risk factors. Stastical significance was set at $\mathrm{p}<0.05$. Analyses were performed with open epi at www. openepi.com.

\section{RESULTS}

In a period of Januari 2012 to December 2014, 63 patients with femoral neck fractures were obtained. Most of the patients (51 or $81 \%$ ) were female. They were between 37 to 89 years old. The same number of control with similar age and gender distribution were invited from the general population. Most of the subjects $(90 \%)$ came from the rural area. All patients had fractures associated with fall, either in the bathroom (27\%), bedroom $(24 \%)$, kitchen $(21 \%)$ or in other places, such as in the living room, in the garden or on the street. More than $75 \%$ of the fall occured indoor.

Corticosteroid were commonly used. Overall, $44.4 \%$ of the cases and almost $10 \%$ of the controls used corticosteroid at least once a month. Similarly, habitual coffee consumption were also a common practice. Around half of the subjects drank coffee daily. Since most of the subjects were elderly, disorder in visual acuity were common. Most of the visual inacuity was due to the need to wear reading eyeglasses. Engagement in regular sport activity, on the other hand, were scarcely done. The odds for having femoral neck fracture for every lifestyle risk was presented in TABLE 1 .

TABLE 1 shows that corticosteroid use, habitual coffee consumption, visual acuity disorder and habitual use of slippers were risk for fractures, while engagement in routine sport was a protecting factor.

TABLE 1. Association between life-style and femoral neck fractures

\begin{tabular}{|c|c|c|c|c|c|c|}
\hline Variables & & $\begin{array}{l}\text { Case } n=63 \\
(\%)\end{array}$ & $\begin{array}{l}\text { Control } \\
n=63(\%)\end{array}$ & OR & $95 \% \mathrm{CI}$ & $\mathrm{p}$ \\
\hline \multirow{2}{*}{$\begin{array}{l}\text { Corticosteroid use (at least once a } \\
\text { month) }\end{array}$} & Yes & $28(44.4)$ & $6(9.5)$ & \multirow{2}{*}{7.48} & \multirow{2}{*}{$2.91-21.6$} & \multirow{2}{*}{$<0.001$} \\
\hline & No & $35(55.6)$ & $57(90.5)$ & & & \\
\hline \multirow{2}{*}{$\begin{array}{l}\text { Habitual coffee consumption (at } \\
\text { least daily) }\end{array}$} & Yes & $52(82.5)$ & $10(15.9)$ & \multirow{2}{*}{24.1} & \multirow{2}{*}{$9.72-64.7$} & \multirow{2}{*}{$<0.001$} \\
\hline & No & $11(16.5)$ & $53(84.1)$ & & & \\
\hline \multirow{2}{*}{$\begin{array}{l}\text { Disorder of visual acuity (use of } \\
\text { eyeglasses or contact lenses) }\end{array}$} & Yes & $43(68.3)$ & $25(39.7)$ & \multirow{2}{*}{3.24} & \multirow{2}{*}{$1.56-6.83$} & \multirow{2}{*}{$<0.001$} \\
\hline & No & $20(31.7)$ & $38(60.3)$ & & & \\
\hline \multirow{2}{*}{ Habitual use of slippers } & Yes & $43(68.3)$ & $17(27.0)$ & \multirow{2}{*}{5.73} & \multirow{2}{*}{$2.68-12.6$} & \multirow{2}{*}{$<0.001$} \\
\hline & No & $20(31.7)$ & $46(73.0)$ & & & \\
\hline \multirow{2}{*}{$\begin{array}{l}\text { Regular sport activity (at least } \\
\text { weekly) }\end{array}$} & Yes & $13(20.6)$ & $21(33.3)$ & \multirow{2}{*}{0.10} & \multirow{2}{*}{$0.02-0.33$} & \multirow{2}{*}{$<0.001$} \\
\hline & No & $50(79.4)$ & $42(66.7)$ & & & \\
\hline
\end{tabular}

\section{DISCUSSION}

This study observed that corticosteroid use was risk factor for fracture. The finding was not suprising since corticosteroid was known to be strongly associated with osteoporosis. However, osteoporosis only explain around half of the incidence of proximal femoral fractures in the elderly. ${ }^{4}$ What was surprising was the prevalence of corticosteroid use in the population studied, more than $40 \%$ of the cases and almost $10 \%$ of the controls use corticosteroid regularly. Population based study in the United states 
observed only around $1.2 \%$ of the population studied were using corticosetroid at the time of the study. Despite the many indications for corticosteroid use, it was wiser to limit its use because of its severe side effects. ${ }^{5}$

It was not clear from this study nor from other previous studies, however, whether the association between corticosteroid use was related to the way the corticosteroid were used: oral, topical, injection etc. It was also not clear yet, whether it was chronic low dose use or intermittent high dose use that was worse for the bone..$^{5}$ Our study observed that habitual coffee consumption was also risk factor for fracture. Liu et al. ${ }^{6}$ in their systematic review reported their support for overall harm of coffee intake in increasing the risk of fractures, especially for women.

Hallstrom et $a .^{7}$ reported that men consuming 4 cups of coffee or more per day had $4 \%$ lower BMD at the proximal femur $(p=0.04)$ compared with low or nonconsumers of coffee. This difference was not observed in women. However, their study also observed no evidence of a higher rate of any fracture $(\mathrm{HR}=0.99 ; 95 \%$ CI $0.98-1.00$ per $200 \mathrm{ml}$ coffee $)$ or hip fracture $(\mathrm{HR}=0.97$; $95 \%$ CI 0.95 - 1.00 per $200 \mathrm{ml}$ coffee) with increasing coffee consumption. A study in rats observed negative interference of coffee consumption on the material and structural bone properties, diminishes trabecular and cortical bone density, and hence making bones more fragile and likely to fractures. ${ }^{8}$ Human physiological studies and controlled balance studies show a clear but only a very small depressant effect of caffeine on intestinal calcium absorption, and no effect on total 24-h urinary calcium excretion. ${ }^{9}$

The epidemiologic studies showing a negative effect may be explained in part by an inverse relationship between consumption of milk and caffeine-containing beverages. Low calcium intake is clearly linked to skeletal fragility, and it is likely that a high caffeine intake is often a marker for a low calcium intake. The negative effect of caffeine on calcium absorption was small enough to be fully offset by as little as 1-2 tablespoons of milk. All of the observations implicating caffeine-containing beverages as a risk factor for osteoporosis were performed in populations consuming substantially less than optimal calcium intakes. There was no evidence that caffeine had any harmful effect on bone status or on the calcium economy in individuals who ingested the recommended daily allowances of calcium. ${ }^{9}$

Visual accuity was also associated with increase risk for fractures. Studies observed, it was not the accuity of the visus that was important, rather than, it was the ability to differ contrast and sense of three-dimension, i.e. the ability to perceived depth, that was an important risk for falling, and hence, risk for fracture. The impairment of the three-dimension perception was especially dangerous when the patient ascends or descends stairs. They lacked the ability to perceived the depth of the steps. What was worse, due to lesser daily activity, visual inaccuity in older people was also seldom recognized..$^{10}$

Sensory impairments affect older adults' ability to interact with and navigate safely in their environment, as demonstrated by the high prevalence of sensory impairment in this sample of hip fracture patients as compared with the general population of community dwelling older adults. ${ }^{10} \mathrm{Cox}$ et al. ${ }^{11}$ observed, in femoral neck fracture patients in Glasgow, bilateral visual impairment (binocular visual acuity worse than 6/12) was found in 239 of 518 patients (46\%). Of this group, the principal causes for visual deficit were untreated cataract (49\%), macular degeneration (21\%), uncorrected refractive error (17\%), and glaucoma (3\%). The visually impaired group were more likely to have symptomatic visual complaints (58 vs $26 \%$ ), however, were less likely to be under optometric care (71 vs $85 \%$ ). A higher proportion of the group with visual impairment lived in areas of social deprivation (40 vs $26 \%$ ).

This study observed that in general, habitual use of slippers was associated with increased risk for fracture. Use of slippers decreased semato-sensoric accuity of the soles, decreased the ability to perceived 
sliperiness of the floor, hence increased the risk for slipping. Slippers, socks or any unstable footwears were not advisable to wear. A prospective cohort study in Boston, however, observed that wearing stable shoes was protective for indoor fall compared to walking barefoot or wearing socks only or slippers or walking in shoes with inadequate fixation (that is, no laces, straps, or buckles), increased heel height, and reduced contact area of sole. ${ }^{12,13}$

Engagement in routine sport was protective for fracture. Beside a proxy for better general health, active life was associated with higher bone density, hence, lower risk for fractures. Subjects who were only able to walk in short distances had 7-8 times higher risk for fractures, while those who were only able to walk few steps or bedridden had 11 times higher risk for fracture. ${ }^{3}$ Our findings support encouregement for active life and engagement in routine sport activity to lessen the risk for fracture. In line with this findings, subjects who had poor self reported health had higher risk for fracture, 8 times higher than those who reported good health, and for times higher than those who reported moderate health, a clear doses dependent association. ${ }^{14,15}$

\section{CONCLUSSION}

This study observes that corticosteroid use, habitual coffee consumption, visual acuity disorder and habitual use of slippers are risk factors for fractures, while engagement in routine sport is a protecting factor. It is necessary to educate people, especially to those who had already have the inevitable risks, to avoid these life styles' risks and to have regular sport activity.

\section{ACKNOWLEDGEMENTS}

We would like to thank the Director of Dr. Sardjito General Hospital for giving the permission and the facilities to perform the study

\section{REFERENCES}

1. Dhanwal DK, Dennison EM, Harvey NC, Cooper C. Epidemiology of hip fracture: worldwide geographic variation. Indian J Orthop 2011; 45(1):15-22. http://dx.doi.org/10.4103/00195413.73656

2. LeBlanc KE, Muncie HL, LeBlanc LL. Hip fracture: diagnosis, treatment, and secondary prevention. Am Fam Physician 2014; 89(12):945-51

3. Kanis JA, Odén A, McCloskey EV, Johansson H, Wahl DA, Cooper C. A systematic review of hip fracture incidence and probability of fracture worldwide. Osteoporos Int 2012; 23(9):2239-56.

http//dx.doi.org/10.1007/s00198-0121964-3

4. Kanis JA, Johansson H, Oden A, Johnell $\mathrm{O}$, de Laet C, Melton LJ, et al. A metaanalysis of prior corticosteroid use and fracture risk. J Bone Miner Res 2004; 19(6):893-9.

h t t p://dx.doi.org/10.1359/ JBMR.040134

5. Overman RA, Yeh J, Deal CL. Prevalence of oral glucocorticoid usage in the United States: a general population perspective. Arthritis Care Res 2013; 65(2):294-8.

http://dx.doi.org/10.1002/acr.21796

6. Liu H, Yao K, Zhang W, Zhou J, Wu T, He C. Coffee consumption and risk of fractures: a meta-analysis. Arch Med Sci 2012; 8(5):776-83.

http://dx.doi.org/10.5114/ aoms.2012.31612

7. Hallström H, Melhus H, Glynn A, Lind L, Syvänen A, Michaëlsson K. Coffee consumption and CYP1A2 genotype in relation to bone mineral density of the proximal femur in elderly men and women: a cohort study. Nutrition Metab $2010 ; 7: 12$

http://dx.doi.org/10.1186/1743-7075-7-12 
8. Santos MP, Pagani JCM, Silva TD, Garcia JAD, Romao MOC, Fernandes GJM, et al. Effects of coffee (Coffea arabica) consumption on the femoral morphology and biomechanics in rats. $\mathrm{J}$ Morphol Sci 2014; 31(1):42-7. http://dx.doi.org/10.4322/jms.ao062513

9. Heaney RP. Effects of caffeine on bone and the calcium economy. Food and Chemical Toxicology 2002; 40(9):1263-70. http://dx.doi.org/10.1016/S02786915(02)00094-7

10. Cacchione PZ. $15.4 \%$ of older people with hip fracture have visual impairment, $38.6 \%$ auditory impairment and $30.1 \%$ combined sensory impairment. Evid Based Nurs 2010; 13(2):59-60. http://dx.doi.org/ 10.1136/ebn1049

11. Cox A, Blaikie A, MacEwen CJ, Jones D, Thompson K, Holding D, et al. Visual impairment in elderly patients with hip fracture: causes and associations. Eye 2005; 19(6):652-6.

h t tp://dx.doi.org/10.1038/ sj.eye. 6701610

12. Kelsey JL, Procter-Gray E, Nguyen US, Li W, Kiel DP, Hannan MT. Footwear and falls in the home among older individuals in the MOBILIZE Boston Study. Footwear Sci 2010; 2(3):123-9. http://dx.doi.org/10.1080/19424280.201 0.491074

13. Spink MJ, Menz HB, Fotoohabadi MR, Wee E, Landorf KB, Hill KD, et al. Effectiveness of a multifaceted podiatry intervention to prevent falls in community dwelling older people with disabling foot pain: randomised controlled trial. BMJ 2011; 342:3411. http://dx.doi.org/10.1136/bmj.d3411

14. Määttä M, Terho E, Jokinen H, Pulkkinen $\mathrm{P}$, Korpelainen $\mathrm{J}$, Heikkinen $\mathrm{J}$, et al. Lifestyle factors and site-specific risk of hip fracture in community dwelling older women--a 13-year prospective population-based cohort study. BMC Musculoskelet Disord 2012; 13:173. http://dx.doi.org/10.1186/1471-2474-13-173

15. Landi F, Onder G, Russo A, Liperoti $\mathrm{R}$, Tosato M, Maria A, et al. Calf circumference, frailty and physical performance among older adults living in the community. Clin Nutr 2014; 33:539-44.

http://dx.doi.org/10.1016/j . clnu.2013.07.013 